\author{
Al-wardah: Jurnal Kajian Perempuan, Gender dan Agama \\ Volume: 12 Nomor: 1 \\ ISSN: 1907-2740, E-ISSN: 2613-9367 \\ DOI: $\mathrm{xxx} \mathrm{xxxx} \mathrm{xxxx}$
}

\title{
PENDIDIKAN AKHLAK PADA ANAK USIA DINI PERSPEKTIF ISLAM
}

\author{
. Hamzah \\ IAIN Ternate,Indonesia \\ hamzahgiling@iain-ternate.ac.id
}

\begin{abstract}
Moral education to children is a very important thing to do by parents. This moral education cannot be ignored by parents, because the function and position of parents does not only provide material aspects, but must pay attention and direct the behavior of their children to the good according to Islamic teachings. through stages, namely the introduction of its creator, doing good to parents, establishing prayers, obliged to submit to goodness and prevent unjust acts, not arrogant to fellow human beings. These stages are carried out through example, teaching, motivation, habituation and giving sanctions. This is done to give birth to moral life, to make life useful and to know and love the creator and fellow human beings.
\end{abstract}

Keywords: Ahlak, Children Aged

Abstrak

Pendidikan akhlak kepada anak merupakan hal yang sangat penting dilakukan oleh orangtua. Pendidikan akhlak ini tidak bisa diabaikan oleh orangtua, karena fungsi dan kedudukan orangtua tidak hanya memberikan aspek materi saja, tetapi harus memperhatikan dan mengarahkan perilaku anak-anaknya kepada yang baik sesuai ajaran Islam. melalui tahapan-tahapan, yaitu pengenalan akan penciptanya, berbuat baik kepada orangtua, mendirikan sholat, berkewajiban menyeruh kepaada kebaikan dan mencegah perbuatan mungkar, tidak sombong pada sesame manusia. Tahapan-tahapan ini dilakukan melalui keteladanan, pengajaran, motivasi, pembiasaan dan pemberian saanksi. Hal ini dilakukan untuk melahirkan kehidupan yang bermoral, menjadikan hidup yang bermanfaat dan mengenal dan cinta kepada penciptanya dan sesama manusia.

Kata kunci : Ahlak, Anak Usia Dni

\section{A. Pendahuluan}

Anak merupakan titipan (amanah) yang diberikan Allah kepada orangtua untuk dididik dan diarahkan kepada kehidupan yang baik sesuai aturan-aturan agama, sehingga anak mendapatkan bekal yang terarah dan dapat bertanggung-jawab dalam hidupnya. Salah satu pendidikan yang harus diberikan kepada anak sedini mungkin adalah pendidikan 
akhlak. Oleh karena itu, pendidikan akhlak merupakan hal yang sangat urgen dalam kehidupan anak.

Dewasa ini, sebagian orangtua bekerja penuh di luar rumah, sehingga tak jarang bertemu anak-anak hanya menjelang malam dan menjelang pagi, akibatnya komunikasi dan pertemuan anak sangat terbatas. Tentu ini menjadi hal yang harus diperhatikan bagaimana menekankan pendidikan akhlak terhadap anak-anak sehingga anak-anak mendapatkan bekal dalam kehidupan. Tentunya pendidikan akhlak yang didapatkan oleh anak-anak harus didapatkan sesuai panduan dan ajaran Islam, agar menjadi jelas dan terarah. Hal ini dilakukan karena problematika kehidupan dewasa ini semakin kompleks dan dinamis. Tidak itu saja, perkembangan tekhnologi dan pengetahuan serta dinamika kehidupan pun dapat mempengaruhi pemikiran dan kehidupan seseorang. Oleh karena itu, perlu arahan yang jelas dan pasti.

Tulisan ini akan menguraikan pendidikan akhlak dalam keluarga menurut Islam, apa yang harus diajarkan orangtua kepada anak-anaknya menurut Islam, sehingga anak-anak mendapat pedoman yang jelas dan standar sedini mungkin sehingga dapat mengarungi kehidupan tanpa meninggalkan ajaran agama, terutama akhlak.

\section{B. Kajian Teori}

\section{Pengertian Pendidikan Akhlaq}

Akhlaq menurut bahasa artinya "budi pekerti, adat kebiasaan, perangai, muru'ah atau segala sesuatu yang menjadi tabi'at. Menurut Imam Abdul Mukmin Sa'adudin (2016:15) ,akhlaq berasal dari bahasa Arab yang merupakan bentuk jamak dari khuluk yang mengandung arti diantaranya:

1. Tabi'at, yaitu sifat dalam diri yang terbentuk oleh manusia tanpa dikehendaki dan diupayakan.

2. Adat, yaitu sifat dalam diri yang diupayakan manusia melalui latihan yakni berdasarkan keinginannya.

3. Watak, yaitu cukupnya meliputi hal-hal yang menjadi tabi'at dan hal-hal yang diupayakan hingga menjadi adat, kata akhlaq juga bisa berarti kesopanan dan agama. 
Menurut Akhyar (2014:1), bahwa akhlak adalah suatu tindakan atau perbuatan, tabiat, adat kebiasaan serta watak seseorang yang ada dalam dirinya.Kata-kata tersebut mengandung segi-segi persesuaian dengan perkataan khalqun yang berarti kejadian, yang juga erat hubungannya dengan khaliq yang berarti sang pencipta.

Baik kata akhlaq dan khuluq dijumpai pemakaiannya baik dalam al-Qur'an dan al Hadist. Didalam Al-qur'an kata ahlaq terdapat pada surat al qalam ayat 4 terjemahannya: ( dan sesungguhnya kamu benar-benar berbudi pekerti yang agung)

Dalam khazanah perbendaharaan bahasa Indonesia kata yang setara maknanya dengan akhlak adalah moral, etika, nilai dan karakter. Kata-kata ini sering disejajarkan dengan budi pekerti, tata susila, tata krama atau sopan santun. Pada dasarnya secara konseptual kata etika dan moral mempunyai pengertian serupa, yakni sama-sama membicarakan perbuatan dan perilaku manusia ditinjau dari sudut pandang nilai baik dan buruk. Akan tetapi dalam aplikasinya etika lebih bersifat teoritis filosofis sebagai acuan untuk mengkaji sistem nilai, sedang moral bersifat praktis sebagai tolak ukur untuk menilai perbuatan yang dilakukan oleh seseorang. Etika memandang perilaku secara universal, sedang moral memandangnya secara lokal.

Dalam Kamus Bahasa Indonesian kata karakter diartikan dengan tabiat, sifat-sifat kejiwaan, akhlak atau budi pekerti yang membedakan seseorang dengan yang lain. Orang berkarakter berarti orang yang berkepribadian, berperilaku, bersifat, bertabiat atau berwatak. Dengan makna seperti itu berarti karakter identik dengan keperibadian atau akhlak.

Dari penjelasan pengertian tentang akhlak dapat ditarik kesimpulan bahwa akhlak adalah budi pekerti, perangai, tingkah laku atau adab yang dilakukan oleh seseorang yang bersifat konstan, spontan, tidak temporer, dan tidak memerlukan pemikiran dan pertimbangan serta dorongan dari luar. Atau perbuatan buruk serta cara menjauhinya, maka akhlak mengandung unsur-unsur antara lain:
a. menjelaskan arti baik dan buruk
b. menerangkan apa yang harus dilakukan
c. menunjukkan jalan untuk melakukan perbuatan
d. menyatakan tujuan dalam perbuatan 
Pendidikan akhlak berkisar tentang persoalan kebaikan dan kesopanan, tingkah laku terpuji serta berbagai persoalan yang timbul dalam kehidupan sehari-hari dan bagaimana seharusnya anak-anak dan keluarga bertingkah laku. Dalam hal ini Yunahar Ilyas (2006:2) mengungkapkan bahwa akhlaq adalah sifat yang tertanam dalam jiwa manusia, sehingga ia akan muncul secara sepontan bilama diperlukan, tanpa perlu pemikiran atau pertimbangan lebih dahulu, serta tidak memerlukan dorongan dari luar.

Dari berbagai penjelasan di atas dapat ditarik kesimpulan bahwa akhlaq adalah budi pekerti, perangai, tingkah laku atau adab yang dilakukan oleh seseorang yang bersifat konstan, spontan, tidak temporer dan tidak memerlukan pemikiran dan pertimbangan serta dorongan dari luar. Atau ilmu yang membahas tentang perbuatan mulia serta cara mengungkapkan perbuatan buruk serta cara menjauhinya.

Pendidikan akhlaq berkisar tentang persoalan kebaikan dan kesopanan, tingkahlaku terpuji serta berbagai persoalan yang timbul dalam kehidupan sehari-hari dan bagaimana seharusnya peserta didik bertingkah laku.

\section{Dasar dan Tujuan Pendidikan Akhlaq}

a. Dasar Pendidikan Akhlaq terjemahannya: (Dan sesungguhnya kamu benar-benar berbudi pekerti yang agung)

b. Terjemahannya:

(Sesungguhnya telah ada pada (diri) Rasulullah itu suri teladan yang baik bagimu (yaitu) bagi orang yang mengharap (rahmat) Allah dan (kedatangan) hari kiamat dan Dia banyak menyebut Allah).

Ayat-ayat di atas menjelaskan bahwa diri Rasulullah itu sudah ada suri tauladan yang baik, karenya merupakan utusan untuk seluruh umat Islam bahkan alam semesta. Oleh karena itu, sebagai ummatnya haruslah dapat mencontoh akhlak beliau. Manusia sebagai ciptaan Allah memiliki Fitrah, maksudnya ciptaan Allah. manusia diciptakan Allah mempunyai naluri beragama Yaitu agama tauhid. kalau ada manusia tidak beragama tauhid, Maka hal itu tidaklah wajar. mereka tidak beragama tauhid itu hanyalah pengaruh lingkungan.

Dari ayat-ayaa di atas, menjelaskan tentang ajaran seorang ayah pada anaknya tentang Akhlaq, yaitu: 
1. Tidak boleh mensyerikatkan Allah, karena syirik adalah perbuatan zalim

2. Berbuat baik kepada dua orang ibu-bapanya;

3. Orangtua harus menyeruh anak-anaknya untuk mendirikan shalat

4. Orangtua harus menyeruh anak-anak untuk mengerjakan yang baik dan cegahlah (mereka) dari perbuatan yang mungkar dan bersabarlah terhadap apa yang menimpa kamu.

5. Seorang ayah harus mengajarkan anak-anaknya agar jangan memalingkan muka dari manusia (karena sombong) dan berjalan di muka bumi dengan angkuh. Sesungguhnya Allah tidak menyukai orang-orang yang sombong lagi membanggakan diri..dan sederhanalah kamu dalam berjalan dan lunakkanlah suaramu. Sesungguhnya seburuk-buruk suara ialah suara keledai

Beberapa prinsip di atas harus diajarkan kepada anak dengan tegas dan jelas, serta orangtua harus menjadi terdepan dihadapan anak-anaknya.

Peneltioan terdahulu dari beberapa peneliti seperti , Ahmad Khoirul Rizal, Strategi guru dalam Penanaman Akhlakul Karimah Pada Anak Usia Dini di PAUD Abdi Pertiwi Desa Sukosari Kecamatan Trenggalek Kabupaten Trenggalek, 2016 Perbedaan terdapat pada fokus penelitian dalam penelitian ini fokus penelitiannya adalah bagaimana pelaksanaan dan upaya guru dalam penanaman akhlakul karimah pada anak usia dini.Persamaan nya menggunakan pendekatan penelitian kualitatif.Metode pengumpulan data yang digunakan adalah wawancara, observasi dan dokumentasi.Objek penelitian anak usia dini

\section{Metode}

Metode penelitianyang digunakan adalah metode kepustakaan. Jenis data dalam penelitian ini adalah data teoritik.Teknik Pengumpulan Data, penulis mengambil sumbersumber dari studi pustaka dengan cara menelaah bacaan dari buku-buku sebagai literatur yang mendukung dengan penelitian ini sebagai landasan teoritik.Teknik analisis data yang digunakan adalah analisis ini disebut juga dengan analisis dokumen yang mana merupakan telaah sistematis mengenai catatan atau dokumen-dokemen sebagai sumber data atau juga sebagai analisis untuk mengetahui tingkat kesulitan dokumen, buku ataupun 


\section{Pendidikan Akhlak Pada Anak Usia Dini..}

teks.Pendekatan yang digunakan adalah pendekatan Psikologi pendidikan yang mana memberikan interpreasi bahwa pendidikan akhlak anak lebih memfokuskan pada perkembangan pola tingkah laku dan kedisiplinan serta keteladanan anak dari segi pembinaan pendidikanya. Terutama dalam pembentukanya kepribadianya dan juga pendekatan filosofis historis yang mana mengungkapkan sejarah atau peristiwa berupa catatan dan dokumen-dokumen.

\section{Hasil}

\section{Hasil Penelitan menunjukan bahwa pendidiakn ahlak kepada anak usia dini} terutama pendidikan akhlak islami wajib diberikan kepada anak sejak usia dini sebagai bentuk tanggung jawab moral orang tua terhadap anak, disamping pengharapan menciptakan generasi yang berprilaku baik (berakhlak mulia) demi kenyamanan, kedamaian dan kebahagian baik dunia maupun akhirat.

\section{E. Pembahasan}

Tujuan pokok pendidikan akhlak menurut Ali Hasan (1979:11), adalah "agar setiap orang berbudi pekerti (berakhlak), bertingkah laku (taabia'at), berperangai atau beradat istiadat yang baik, yang sesuai dengan ajaran Islam”. Tujuan pendidikan akhlak menurut Barmawie Umarie (1991:4), adalah supaya dapat terbiasa melakukan yang terbaik, indah, mulia, terpuji, serta menghindari yang buruk, jelek, hina dan tercela.

Dari dua pendapat di atas, dapat disimpulkan bahwa tujuan pendidikan dari akhlak agar setiap manusia bertingkah laku dan bersikap yang baik serta terpuji baik lahir maupun bathin serta tindakan dan perbuatan hendaklah dijiwai oleh imam serta ketakwaan kepada Allah SWT. Untuk mencapai tujuan pendidikan akhlak ini maka ada beberapa metode yang dapat dilakukan.Abuddin Nata (1979:11),mengatakan pendidikan akhlak merupakan tumpuan perhatian pertama dalam Islam.Hal ini dapat dilihat dari salah satu misi kerasulan Nabi Muhammad SAW, yang utama adalah untuk menyempurnakan akhlak yang mulia. Perhatian Islam yang demikian terhadap pendidikan ini dapat pula dilihat dari perhatian Islam terhadap pendidikan jiwa yang harus didahulukan daripada pendidikan fisik, karena dari jiwa yang baik ini lah akan hadir perbuatan-perbuatan yang baik, yang pada tahap 
selanjutnya akan mempermudah menghasilkan kebaikan dan kebahagian pada seluruh kehidupan manusia, lahir dan bathin.

Dari uraian di atas, dapat disimpulkan bahwa pendidikan akhlak itu tidak hanya mengajarkan ilmu pengetahuan agama Islam, mendidik anak agar taat menjalankan agama dan pada fisik saja, akan tetapi terlebih dahulu untuk mengajarkan melalui jiwa seseorang tersebut, karena seseorang itu berjiwa baik maka akan baik juga lah perbuatannya. Akhlak Menurut Zainudin Ali (2007:30) atau sistem prilaku dapat diwujudkan sekurangkurangnhya dengan dua pendekatan:

1. Rangsangan, yaitu perilaku manusia yang berwujud karena adanya dorongan dari suatu keadaan. Keadaan yang dimaksud, terwujud karena adanya pelatihan, tanggungjawab, mencontoh dan sebagainya.

2. Kognitif adalah penyampaian informasi yang dilandasi oleh dalil-dalil al-Qur'an dan hadits, teori dan konsep. Hal dimaksud dapat diwujudkan melalui dakwah, ceramah, diskusi, drama dan sebagainya.

Kedua pendekatan di atas akan terwujud lebih baik jika dilakukan dengan pembiasaan yang merupakan sarana pembentukan akhlak dalam keluarga, terutama pada anak-anak oleh orangtua. Pembiasaan yang dilakukan orangtua yang merupakan tauladan dalam keluarga merupakan rangsangan dan contoh terhadap anak-anak dan lingkungan keluarga. Orangtua merupakan contoh dalam pembiasaan sifat-sifat yang baik dalam kehidupan keluarga, sehingga anak akan hidup dari kecil sampai dewasa dalam sifat-sifat yang baik. Pembiasaan-pembiasaan ini sangat penting dalam pembentukan akhlak.Pembiasaan-pembiasaan dan latihan ini melahirkan perbuatan atau ucapan yang baik.

Menurut Alex Gunur dalam bukunya "Etika Sebagai Dasar Dan Pedoman Pergaulan" sebagaimana yang dikutip oleh Akhyar sebagai berikut:

a. Mengetahui dan menyadari bagaimana seharusnya berperilaku atau bertingkah laku yang baik.

b. Menjalankan atau mempraktekkan dalam hidup sehari-hari apa yang telah diketahui itu, yakni menjalankan hal-hal yang baik saja dan mengelakkan yang buruk. 
Menurut Abdul Mustaqim (2013-8-9),di samping diperlukan ilmu (pemahaman yang benar tentang mana yang baik dan mana yang buruk), untuk membentuk akhlak seseorang diperlukan proses-proses tertentu, antara lain:

1. Melalui keteladanan (Qudwah, uswah). Orangtua dan guru yang biasa memberikan keteladanan mengenai perilaku baik, maka biasanya akan ditiru oleh anak-anaknya dan muridnya dalam mengembangkan pola perilaku mereka. Tidaklah berlebihan jika Imam al-Ghazali pernah megibaratkan bahwa orangtua itu biasanya akan ditiru oleh anak-anaknya. Artinya, perilaku orangtua itu biasanya akan ditiru oleh anakanaknya.Karena dalam diri anak-anak terdapat kecenderungan suka meniru (hubbub al-taqlid).

Oleh sebab itu, keteladanan moral orangtua sangat penting bagi pendidikan moral anak.Bahkan hal itu jauh lebih bermakna daripada sekedar nasehat lisan (indoktrinasi). Jangan berharap anak akan bersifat sabar, jika sebagai orangtua memberi contoh sikap yang selalu marah-marah. Adalah mimpi di siang bolong, orangtua yang mendambakan punya anak berlaku sopan dan bertutur kata lembut, namun dirinya sendiri sering berkata kasar dan kotor (jorok). Keteladanan yang baik merupakan kiat yang mujarab (cespleng) dalam mengembangkan perilaku moral bagi anak.

2. Melalui ta'lim (pengajaran). Misalnya dengan mengajarkan empati dengan sikap disiplin.Tidak perlu menggunakan cara-cara "kekuasaan dan kekuatan". Sebab cara tersebut cenderung mengembangkan moralitas yang eksternal, yaitu anak berbuat baik sekeder takut hukuman orangtua atau guru. Pengembangan moral yang dibangun atas dasar rasa takut cenderung membuat anak menjadi kurang kreatif. Bahkan ia juga menjadi kurang inovatif dalam berfikir dan bertindak, sebab ia selalu dibayangi rasa takut dihukum dan dimarahi orangtua atau gurunya.

Anak jangan dibuat takut kepada orangtua atau guru, melainkan ditanamkan sikap hormat dan segan.Sebab jika hanya karena rasa takut, anak cenderung berperilaku baik ketika orangtua atau gurunya. Namun begitu anak keluar dari rumah atau sekolah dan orangtua atau gurunya tidak mengetahui, maka ia akan berani melakukan penyimpangan moral. Tidaklah mengherankan jika anak yang ketika di 
rumah atau di sekolah tampak baik-baik saja, penurut dan sopan, namun ternyata di luar ia suka 'nyabu' (mengkonsumsi sabu-sabu), mencuri atau melakukan tindak criminal lainnya.

3. Pembiasaan (ta'wid). Melatih anak atau murid dengan perbuatan terpuji yang bisa membentuk keperibadiannya. Sebagai contoh anak sejak kecil dibiasakan membaca basmalah sebelum makan, makan dengan tangan kangan, bertutur kata dengan baik, dan sederet sifat terpuji lainnya. Jika hal itu dibiasakan, maka akan menjadi akhlak mulia bagi anak ketika ia tumbuh dewasa.

4. Pemberian motivasi (Targhib/reward, motivasion), memberikan motivasi baik berupa pujian atau hadiah tertentu, akan menjadi salah satu latihan positif dalam proses pembentukan akhlak, terutama, ketika ia masih kecil. Secara psikologis seseorang memerlukan motivasi atau dorongan ketika hendak melakukan sesuatu. Motivasi itu pada awalnya mungkin masih bersifat material, tetapi nantinya akan meningkat menjadi motivasi yang bersifat spiritual. Jika ketika ia masih anak-anak mengerjakan shalat jamaah hanya karena ingin mendapatkan hadiah orangtua, maka lama-lama menjadi sadar bahwa beribadah karena kebutuhan untuk mendapatkan ridha dari Allah.

5. Pemberian ancaman dan sangsi hukum (Tarhib/punishment, warning). Dalam rangka proses pembentukan akhlak kadang diperlukan ancaman, sehingga anak tidak bersikap sembrono. Dengan begitu, anak ketika mau melanggar norma tertentu akan merasa segan, apalagi jika sangsi hukumannya cukup berat. Kadang juga perlu memaksa diri untuk berbuat baik, sebab terpaksa berbuat baik, jelas itu lebih baik daripada berbuat maksiat dengam kesadaran diri sendiri, sehingga jika besok di akhirat terpaksa masuk surga, jelas itu lebih baik daripada masuk nereka dengan kesedaran diri sendiri.

Akhlak pada prinsipnya adalah ajaran filsafat hidup (the philosophy of life). Ajaran Akhlak memberikan tuntutan kepada keluarga tentang bagaimana hidup ini menjadi lebih baik dan bermakna.Ajaran-ajaran seperti, ikhlas beramal, tidak sombong, hidup sederhana, tidak hedonis, tanggung-jawab, memegang amanah, sabar, pandai bersyukur atas karunia Allah dan lain-lainnya, merupakan ajaran yang sangat mulia dan merupakan moral/akhlak 


\section{Pendidikan Akhlak Pada Anak Usia Dini..}

yang bersifat universal.Ajaran-ajaran tersebut diakui oleh semua orang yang berakal dan berhati sehat. Maka apabila seseorang belajar akhlak dengan benar, lalu ia mau mengamalkannya dengan sungguh-sungguh, maka akan bermanfaat tidak saja bagi diri sendiri tetapi juga bagi orang lainnya. Manfaatnya antara lain: Melahirkan keluruhan moral berupa kesalehan ritual kepada Allah dan kesalehan sosial terhadap sesame manusia. Islam sangat menekankan prinsip tawazum (keseimbangan) dalam membangun peradaban.Kesalehan ritual saja (misalnya, melakukan shalat atau rajin wiridan) itu tidak cukup, karena bisa menyebabkan seseorang menjadi egois dan a-sosial.Oleh sebab itu, perlu juga dihiasi dengan kesalehan sosial. Spritulisme yang ekstrem yang mengabaikan aspek sosial, jelas hanya akan merugikan umat Islam.

a. Menjadikan hidup ini lebih bermakna. Orang yang mengamalkan ajaran akhlak akan menyadari bahwa hidup di dunia ini sementara. Hidup sesungguhnya adalah kesempatan untuk menabung amal shaleh, sekaligus sebagai investasi di akhirat nanti.

b. Muraqabah dan ma'rifatullah, yaitu seseorang merasa bahwa seluruh amal perbuatannya berada dalam pengawassan Allah. Ini akan melahirkan moral otonom. Di mana dan kapan pun berada, ia akan berusaha maksimal mungkin untuk berbuat yang terbaik.

c. Mahabbah fillah( cinta kepada Allah), dengan dasar cinta, semangat berkorban seseorang akan menggelora, semangat berkorban untuk orang lain pun tak pernah padam. Sebab cinta memberikan cinta, maka harus berani berkorban.Cinta tanpa pengorbanan adalah cinta palsu.Dengan dasar cinta kepada Allah, dia mau berkorban untuk meraih ridha-Nya.Ia pun akan menebar cinta kasih kepada sesama umat manusia.

\section{F . Simpulan}

Pendidikan akhlak pada anak harus dilakukan sedini mungkin, melalui tahapan-tahapan, yaitu pengenalan akan penciptanya, berbuat baik kepada orangtua, mendirikan sholat, berkewajiban menyeruh kepaada kebaikan dan mencegah perbuatan mungkar, tidak somobong pada sesame manusia. Tahapan-tahapan ini dilakukan melalui keteladanan, 
pengajaran, motivasi, pembiasaan dan pemberian saanksi. Hal ini dilakukan untuk melahirkan kehidupan yang bermoral, menjadikan hidup yang bermanfaat dan mengenal dan cinta kepada penciptanya dan sesama manusia.

\section{DAFTAR PUSTAKA}

Ali, Zainuddin (2007), Pendidikan Agama Islam, Jakarta: Bumi Akasara.

Akhyar (2014), Akhlak, Riau, LP2M, 2014

Arifin,M.(1996), Ilmu Pendidikan Islam, Jakarta: Bumi Aksara

Daud Ali, Muhammad(2006), Pendidikan Agama Islam, Jakarta: Raja Grafindo.

Departemen Agama RI(2002), Al-Q ur'an dan Terjemahannya, Surabaya: PT. Bina Ilmu.

Departemen Pendidikan dan Kebudayaan (1999), Kamus Besar Bahasa Indonesia, Ed. II Jakarta: Balai Pustaka,

Derajat Zakiah(1993), Ilmu Jiwa Agama, Jakarta: Bulan Bintang.

Ghazali(2006), Bidayatul Hidayah, Bimbingan Menggapai Hidayah, Penerj. Mujahiddin Muhayan dkk., Jakarta: Menara.

Hasan,Ali (1979),Tuntunan Akhlak, Jakarta: Bulan Bintang.

Hussein Muhammad, "Membongkar Konsepsi Fikih tentang Perempuan", dalam Syafiq Hasyim (ed.), Kepemimpinan Perempuan dalam Islam, t.t.: JPPR, t.th

Hornby A.P A.S. Cowic (ed.)(1974), Oxford Advanced Leaner's Dictionary of Current English, London: OxfordUniversity Press.

Ibnu Sulayman 'Arafa ,Muhammad Ibnu 'Abdillah (1980), Huq- q atMar'ah fi al-Islam, Edisi III, t.t.: al-Maktab al-Islamiy, 1980.

Ilyas, Yunahar (2004), Kuliah Akhlaq, Yogyakarta: PPI UMY.

Ilyas, Yunahar(1997), Feminisme Dalam Kajian Tafsir Al-Qur'an : Klasik dan Kontemporer, Cet. I; Yogyakarta: Pustaka Pelajar,

Miskawih, al-Aby Ali Ahmad (1994), Menuju Kesmpurnaan Akhlak, Bandung: Mizan. 
Pendidikan Akhlak Pada Anak Usia Dini..

M.Shihab,Quraish. (1996), Wawasan Al-Qur'an: Tafsir Maudhu'i Atas Pelbagai Persoalan Umat, Cet. III; Bandung: Mizan.

Mukmin Sa"aduddin Abdul (1016), Meneladani Akhlaq Nabi (Membangun Keperibadian Muslim), Bandung: PT. Remaja Rosda Karya.

Mustaqim,Abdul (2013), Akhlak Tasawuf, Yogyakarta: Kaukaba Dipantara.

Nata,Abuddin (2002), Akhlak Tasauf, Jakarta: Raja Grafindo Persada.

Redja Mudiyaharjho (2002), Pengantar Pendidikan : Sebuah Studi Awal Tentang: Dasardasar Pendidikan pada Umumnya dan Pendidikan di Indonesia, Jakarta: PT. Raja Grafindo Persada.

Tim Penyusun Kamus Pusat Pembinaan dan Pengembangan Bahasa (1989), Kamus Besar Bahasa Indonesia, Cet. II; Jakarta; Balai Pustaka

Umarie ,Barmawie (1991), Materi Akhlak, Solo: Ramadhan.

Vitalaya, Aida S. Hubeis (2010), Pemberdayaan Perempuan dari Masa ke Masa, Bogor: IPB Press 